\title{
Forest and rangeland owners value land for natural amenities and as financial investment
}

\author{
by Shasta Ferranto, Lynn Huntsinger, Christy \\ Getz, Gary Nakamura, William Stewart, Sabrina \\ Drill, Yana Valachovic, Michael DeLasaux and \\ Maggi Kelly
}

Forty-two percent of California's forests and rangelands are privately owned (34 million acres). These lands provide important ecosystem services such as carbon sequestration, pollination and wildlife habitat, but little is known about the people who own and manage them. We surveyed forest and rangeland owners in California and found that these long-time landowners value their properties for their natural amenities and as a financial investment. Owners of large properties (500 or more acres) were significantly more likely to use their land for income production than owners of smaller properties, and they were also more likely to carry out or be interested in environmental improvements. Many forest and rangeland owners reported they had been previously approached to sell their land for development. Only about one-third had participated in conservation programs; few had conservation easements. This survey can help guide outreach and education efforts, and the development of information, policies, programs and financial incentives for landowners.

$\mathrm{O}$ ver the last 20 years, an "inmigration" of new landowners has occurred in California's forests and rangelands. Rural housing trends in California mirror similar trends in the nation: between 1940 and 2000, 10\% of private forests and rangelands were fragmented into areas with more than one house per 20 acres (CDFFP 2003). The ecological and management impacts of exurban parcelization include decreased biodiversity

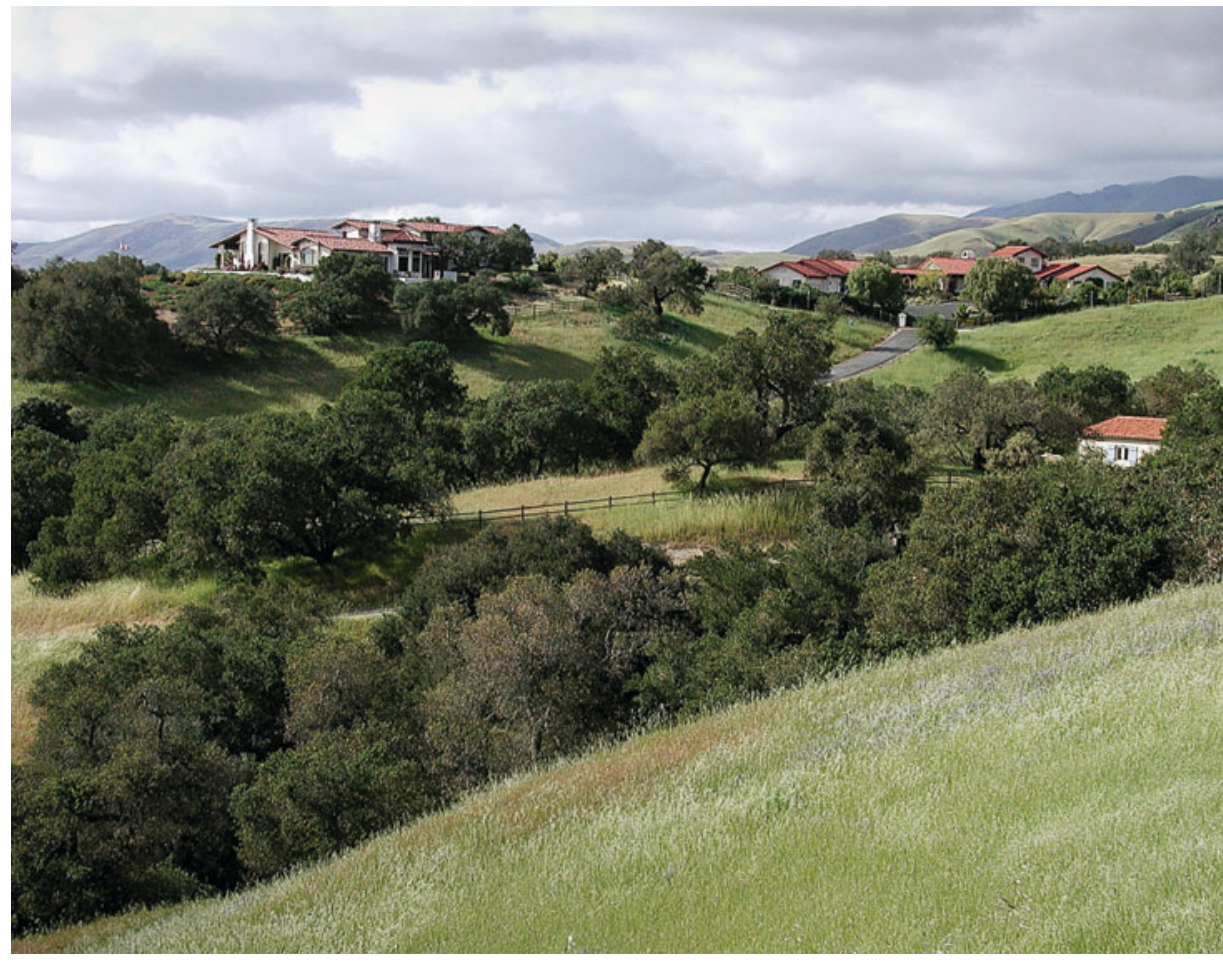

A survey of forest and rangeland property owners in California found that the vast majority value their land for its natural beauty, and they voluntarily undertook environmental improvements and management practices. Above, an exurban development in coastal California.

(Hansen et al. 2005; Maestas et al. 2003; Parmenter et al. 2003), fragmentation of wildlife habitat (Hobbs et al. 2008) and more-difficult wildfire management (Moritz and Stephens 2008).

Changes in land ownership can also bring changes in social values and demographic characteristics. In-migrants seeking a better quality of life may more strongly support protection of amenity values, such as scenery and recreation, and more often participate in environmental activism (Jones et al. 2003). These values may conflict with more traditional views held by long-time residents (Walker and Fortmann 2003; Yung and Belsky 2007). New residents may also have less expertise in land management (Kendra and Hull 2005) or different views than long-term landowners on how undeveloped landscapes should be managed (Gosnell et al. 2006). These changes raise questions: As properties become fragmented into smaller management units, how do the goals and needs of landowners change? Do they use or manage their land differently? And what do these changes imply for future environmental sustainability?

Several studies have examined the physical patterns of fragmentation in the United States (Brown et al. 2005), and many predict future patterns of increased parcelization (Alig and Plantinga 2004; Nowak and Walton 2005; Theobald 2005; White et al. 2009). Few studies, however, have examined the social changes associated with fragmentation or the ecological implications of these changes. These issues are especially pertinent to California forests and rangelands, where fragmentation is predicted to continue (CDFFP 2003). Limited knowledge of the landowner population in California has made it difficult to assess this population and to establish a baseline for understanding how it might change over time, or with interventions of information, policy or financial resources. To improve outreach and education programs geared

Online: http://californiaagriculture.ucanr.org/ landingpage.cfm?article=ca.v065n04p184\&fulltext=yes DOl: 10.3733/ca.v065n04p184 
to landowners, a team of UC Cooperative Extension and UC Berkeley researchers surveyed California forest and rangeland owners in 2008.

\section{Survey design and analysis}

There are approximately $34 \mathrm{mil}-$ lion acres of privately owned forest and rangeland in California, concentrated in the Sierra Nevada and coastal regions (CDFFP 2003). Forest and rangeland owners with parcels greater than 3 acres from 10 California counties were mailed a questionnaire. Eight of the state's 10 bioregions contain forests or rangelands, as defined by the California Department of Forestry and Fire Protection (CDFFP, now known as Cal Fire) for natural resources assessment purposes. A minimum of one county was selected from each. Together, these eight bioregions contain $89 \%$ of the state's private forests and rangelands (CDFFP 2003). We sampled counties representative of each bioregion: Contra Costa, El Dorado, Humboldt, Mendocino, Plumas, San Diego, Santa Barbara, Shasta, Sierra and Sonoma (fig. 1). Because they have small populations, Sierra and Plumas counties, which are adjacent to one another, were treated as a single sampling unit.

Within each county, survey recipients were selected using a stratified random sampling design. The sample was drawn from a statewide land parcel database created in 2003 by CDFFP for the Forest and Range Assessment (CDFFP 2003). The database contains information on parcel size derived from county assessor tax records, and vegetation type at the parcel center derived from satellite imagery. Parcel vegetation type was categorized into either forest, including conifer and hardwood, or rangeland, including oak woodlands, grassland and shrubland.

Parcel size was then subcategorized into four groups: 3 to 9 acres, 10 to 49 acres, 50 to 499 acres, and 500 or more acres. A random sample of up to 30 parcels was drawn from each subcategory, for a total of approximately 240 parcels per county. All duplicate landowner addresses were dropped, so that landowners received only one survey regardless of how many parcels they owned.

We mailed the survey and follow-ups to 1,730 landowners in spring 2008 , following a modified version of the Dillman Total Design Method (Clendenning et al.
2004; Dillman 2007). The questionnaire was a 17-page booklet with 38 questions, many of which contained multiple parts. Most questions were close-ended, with either categorical or Likert scale response choices. Respondents were also offered the option of taking an identical online survey. Questionnaires were returned by 670 people, with $8 \%$ answering online. After adjusting for undeliverable questionnaires and those sent to people who were not forest or rangeland owners, the final response rate was $42.5 \%$.

A stratified sampling design ensured the inclusion of owners from all property sizes but created a sample disproportionate to true population ratios. Unless otherwise indicated, all data was weighted proportionally to sampling intensity to adjust for a disproportionate sampling intensity between different sampling strata. Proportional survey weights were calculated by multiplying the reciprocal sampling ratio (i.e., the total number of landowners in each sampling strata compared to the number of landowners sampled from each strata) by the overall sampling ratio (the overall sample size compared to the overall population) (Maletta 2007). Reported results are thus representative of true landowner population ratios.

All data analysis was done with SPSS 17.0 statistical software. Results are reported as percentages of the total number of respondents to each question. Several questions were based on a Likert scale from 1 to 5, ranging from "not at all important" (value =1) to "highly important" (value = 5). Results for all Likert scale questions were grouped so that a response of "not important" included values 1 and 2, and a response of "important" included values 4 and 5. Comparisons between property sizes were based on the same size categories as used in the sampling ( 3 to 9 acres, 10 to 49 acres, 50 to 499 acres, and 500 or more acres), but respondents were reclassified based on the reported size of all the parcels owned and managed as a single property, rather than on assessor parcel records. (We use the term "property" when referring to the full property, and "parcel" when referring to a single parcel.) Differences in responses by property size were calculated using either Pearson's chi-square analysis for categorical data or analysis of variance (ANOVA) for continuous data.

\section{Profile of landowners}

Respondents were mostly male, over 60 and predominantly married or living with a partner. Few had children living at home, and they tended to be well educated and relatively affluent, with just over half earning more than $\$ 100,000$ and just under one-third earning more than $\$ 200,000$ per year (table 1). These results did not vary substantially based on property size, with the exception that property owners with 50 to 499 acres were significantly more likely to have a bachelor's degree, more likely to have children living at home and more likely to earn over $\$ 200,000$ per year than landowners in other property size categories.

The most common careers, with about one-third of landowners in each category, were professional or management 
positions, retired and self-employed, with only slight variation between property sizes. Only 14\% of respondents reported production-oriented enterprises (timber, agriculture or range) as their profession.

Ownership demographics. On average, respondents had owned their land or the land had been in their family for
31 years. The average length of ownership increased with property size; the most notable increase in land tenure was in the largest property size category (500 or more acres) (table 2). Most owned their land as private individuals (the landowner's name is on the deed). Owners of the largest properties (500 or more acres) were significantly more likely to be

TABLE 1. Demographic profile of California forest and rangeland owners based on property size, 2008

\begin{tabular}{|c|c|c|c|c|c|c|c|c|}
\hline & & $\begin{array}{c}\text { All } \\
\text { landowners }\end{array}$ & $\begin{array}{l}3 \text { to } 9 \\
\text { acres }\end{array}$ & $\begin{array}{l}10 \text { to } 49 \\
\text { acres }\end{array}$ & $\begin{array}{c}50 \text { to } 499 \\
\text { acres }\end{array}$ & $\begin{array}{c}500 \text { or } \\
\text { more } \\
\text { acres }\end{array}$ & $P$ value* & $n$ \\
\hline $\begin{array}{l}\text { Age } \\
\text { (years) }\end{array}$ & Mean age & 62 & 63 & 61 & 60 & 64 & 0.02 & 516 \\
\hline \multirow[t]{2}{*}{$\begin{array}{l}\text { Gender } \\
(\%)\end{array}$} & Male & 65 & 67 & 65 & 62 & 65 & \multirow{2}{*}{0.62} & \multirow{2}{*}{578} \\
\hline & Female & 35 & 32 & 33 & 38 & 35 & & \\
\hline \multirow[t]{2}{*}{$\begin{array}{l}\text { Education } \\
\text { (\%) }\end{array}$} & $\begin{array}{l}\text { At least some } \\
\text { college }\end{array}$ & 90 & 92 & 86 & 92 & 90 & 0.19 & 568 \\
\hline & $\begin{array}{l}\text { Bachelor's } \\
\text { degree or higher }\end{array}$ & 65 & 56 & 65 & 75 & 61 & 0.01 & 568 \\
\hline $\begin{array}{l}\text { Marital } \\
\text { status (\%) }\end{array}$ & Married & 81 & 77 & 81 & 84 & 83 & 0.48 & 576 \\
\hline $\begin{array}{l}\text { Children } \\
(\%)\end{array}$ & $\begin{array}{l}<18 \text { years, living } \\
\text { in household }\end{array}$ & 22 & 14 & 19 & 35 & 15 & 0.00 & 515 \\
\hline \multirow[t]{2}{*}{$\begin{array}{l}\text { Income } \\
(\%)\end{array}$} & $>\$ 100,000$ & 56 & 55 & 48 & 64 & 56 & 0.06 & 523 \\
\hline & $>\$ 200,000$ & 30 & 23 & 22 & 39 & 36 & 0.00 & 523 \\
\hline
\end{tabular}

TABLE 2. Ownership demographics among California forest and rangeland owners based on property size, 2008

\begin{tabular}{|c|c|c|c|c|c|c|c|c|}
\hline & & $\begin{array}{c}\text { All } \\
\text { landowners }\end{array}$ & $\begin{array}{l}3 \text { to } 9 \\
\text { acres }\end{array}$ & $\begin{array}{c}10 \text { to } \\
49 \\
\text { acres }\end{array}$ & $\begin{array}{c}50 \text { to } \\
499 \\
\text { acres }\end{array}$ & $\begin{array}{c}500 \text { or } \\
\text { more } \\
\text { acres }\end{array}$ & $P$ value* & $n$ \\
\hline \multirow[t]{2}{*}{$\begin{array}{l}\text { Land tenure } \\
\text { (years) }\end{array}$} & $\begin{array}{l}\text { Mean length of } \\
\text { ownership }\end{array}$ & 31 & 19 & 21 & 29 & 60 & 0.00 & 629 \\
\hline & Std. deviation & 29 & 12 & 15 & 23 & 41 & & \\
\hline \multirow{5}{*}{$\begin{array}{l}\text { Ownership } \\
\text { type (\%) }\end{array}$} & Private individual(s) & 70 & 80 & 79 & 67 & 45 & 0.00 & 596 \\
\hline & Trust & 19 & 16 & 18 & 24 & 17 & & \\
\hline & LLC & 3 & 0 & 0 & 0 & 18 & & \\
\hline & Partnership & 2 & 1 & 2 & 1 & 7 & & \\
\hline & Other & 5 & 3 & 2 & 7 & 13 & & \\
\hline $\begin{array}{l}\text { Residency } \\
\text { (\%) }\end{array}$ & Primary & 60 & 72 & 63 & 55 & 49 & 0.00 & 600 \\
\hline \multirow{2}{*}{$\begin{array}{l}\text { Nonresident } \\
\text { property uses } \\
\text { (\% of } \\
\text { nonprimary } \\
\text { residents) }\end{array}$} & $\begin{array}{l}\text { Vacation or second } \\
\text { home }\end{array}$ & 46 & 43 & 54 & 35 & 54 & 0.09 & 218 \\
\hline & Rental unit & 7 & 2 & 7 & 15 & 0 & 0.01 & 218 \\
\hline
\end{tabular}

in corporate ownership — often a family corporation (table 2). The majority of respondents were primary residents. Owners were less likely to be primary residents as property size increased, with an almost equal ratio of primary to nonprimary residents in the largest property size category. Of the nonprimary residents, $46 \%$ used the land as a second, seasonal or vacation home, with no significant variation based on property size (table 2). Nonprimary residents tended to live fairly far from the property $-77 \%$ lived more than 20 miles away, and 44\% lived more than 100 miles away.

Reasons for ownership. A variety of reasons were reported for owning land. To "live near natural beauty" was the objective ranked by most landowners as important (fig. 2). Other popular reasons included "land value appreciation," "escape from city crime and pollution," "financial investment" and "live in a small community." In general, amenity values and financial investment objectives were important to the most landowners.

When broken down by property size, several notable differences became evident. All property sizes ranked living near natural beauty and financial appreciation of the land as important. Only a small percentage of small property owners (less than 50 acres) considered family tradition or business as important; about half of landowners with 50 to 499 acres marked it as important; but this was the single most important objective for owners of large properties (500 or more acres) (fig. 3). Income source was not considered important to most owners of small properties but was important to over three-fourths of large property owners. In contrast, owners of large properties were less concerned than owners of small properties about escaping from the city, living in a small community or having a simpler lifestyle (fig. 3).

\section{Resource use}

Overall, landowners were more likely to utilize their land's resources such as timber, livestock forage or game for personal use than for income production (fig. 4). Only one-third reported earning income in one of the provided ways, while almost three-fourths used their land's natural resources for personal use.

As property size increased, landowners were more likely to use their land 
for income (fig. 4A). Over half of landowners with the largest properties (500 or more acres) harvested timber for income, and just under $40 \%$ raised livestock (fig. 4A). Hunting and fishing for personal use also increased with property size, but raising food crops or livestock, and harvesting timber for personal use all remained constant or decreased slightly as property size increased (fig. 4B). Harvesting fuelwood for personal use increased with property size until the 50-to-499-acre category, then dropped substantially in the 500-or-more-acres category (fig. 4B).

\section{Land management practices}

California forest and rangeland owners implemented a variety of land management practices for environmental

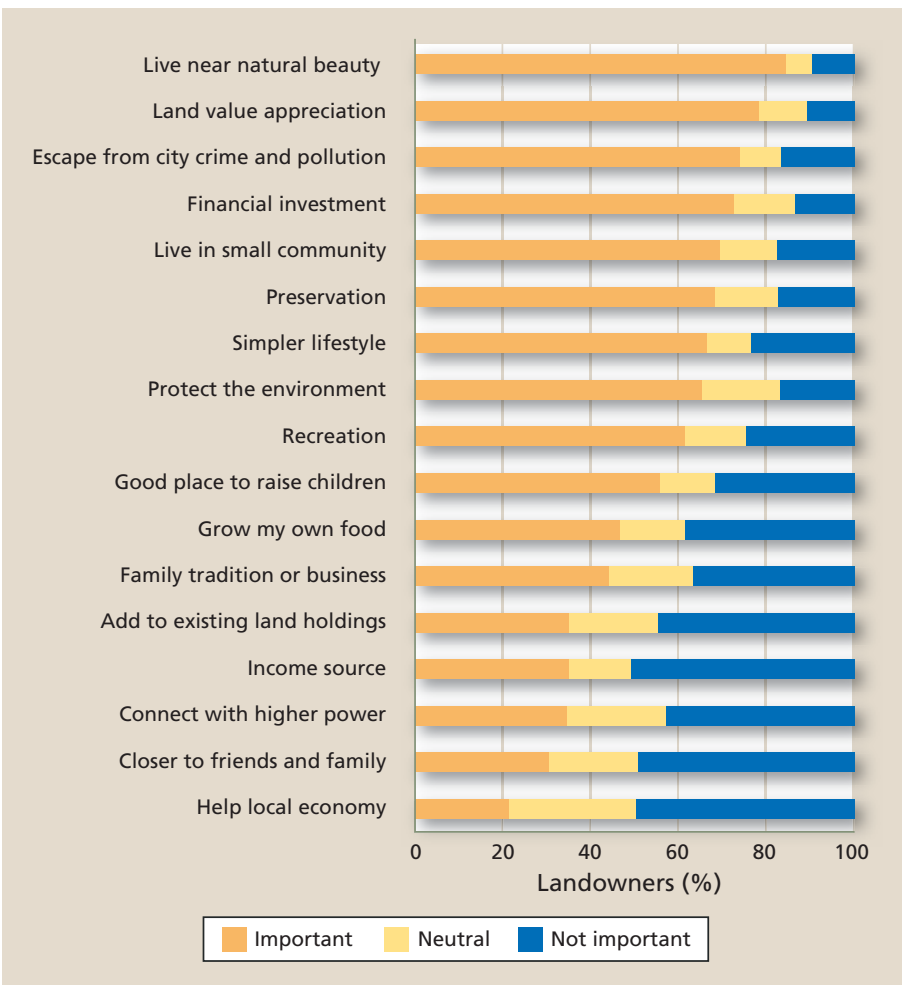

Fig. 2. California forest and rangeland owners' reasons for owning land $(n=578), 2008$

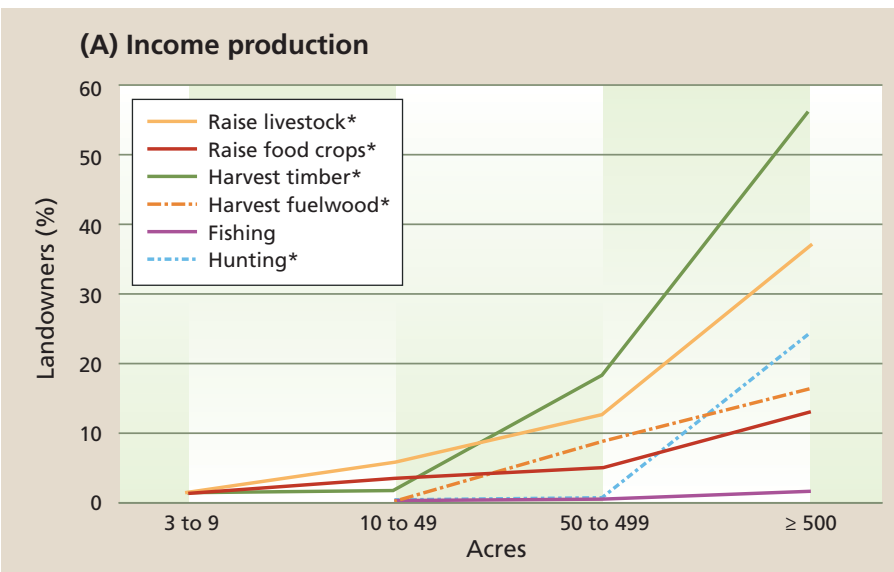

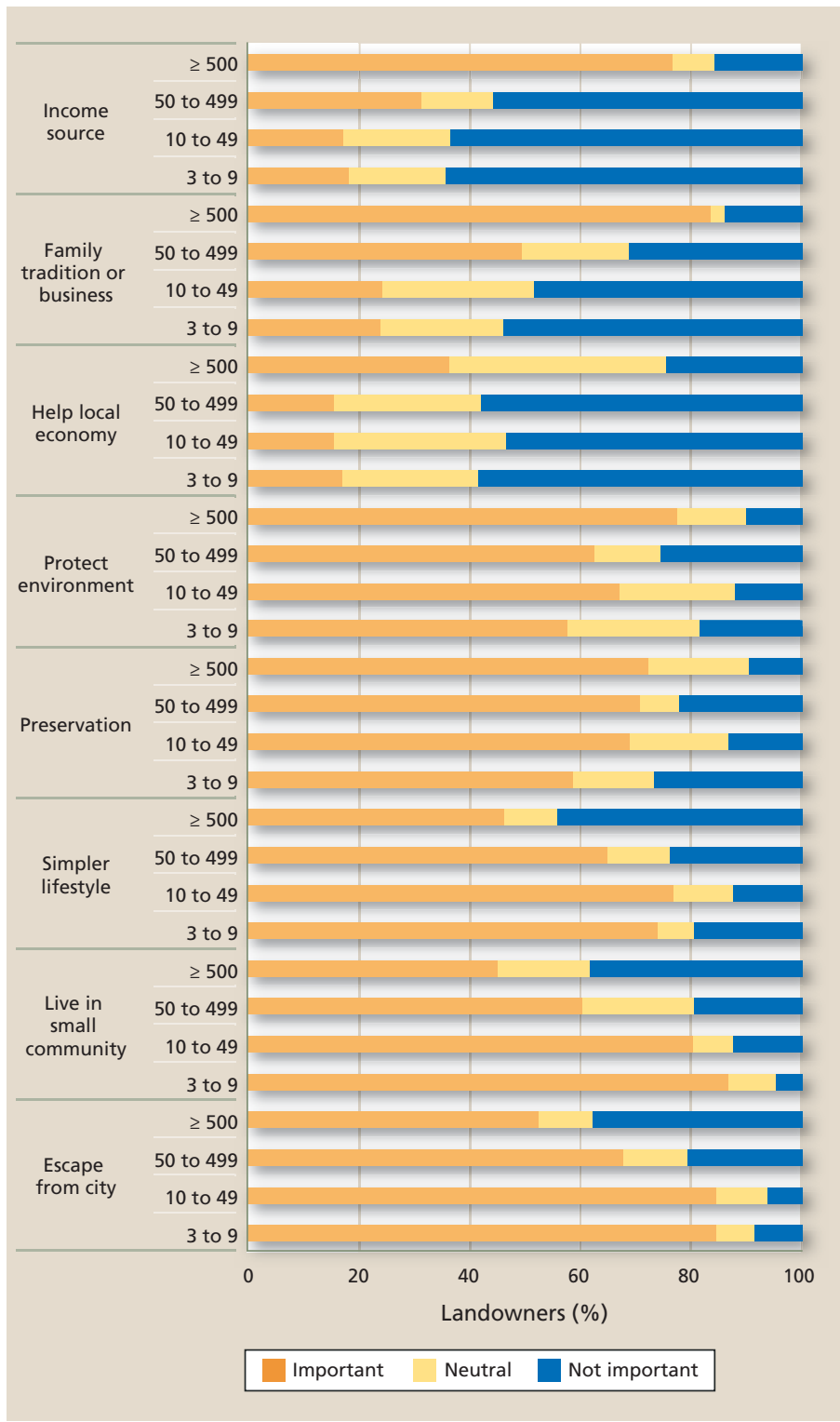

Fig. 3. California forest and rangeland owners' reasons for owning land based on property size, 2008. Ownership objectives with significant differences between property sizes are shown (chi-square analysis, $P<0.01, n=566$ ).

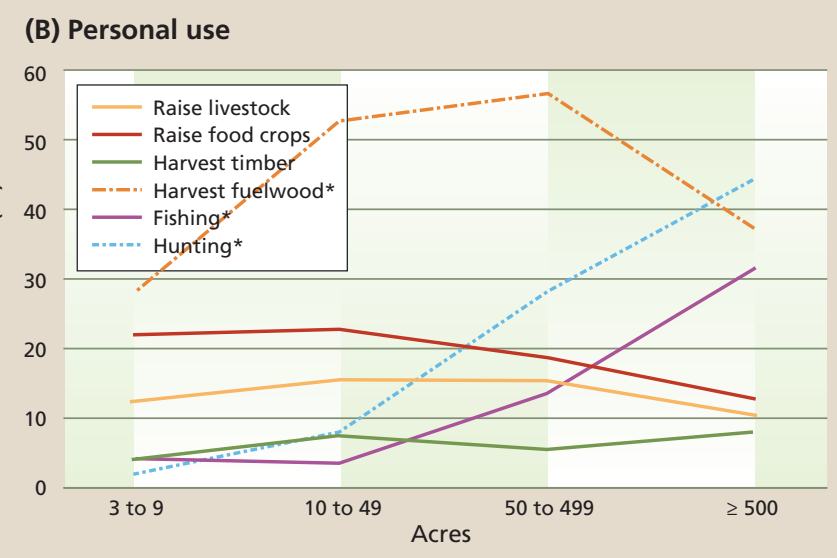

Fig. 4. (A) Income production from and (B) personal use of natural resources based on property size for California forest and rangeland owners, 2008; $80 \%$ of owners use resources in one of the ways shown $\left(^{*}=\right.$ significant difference between property sizes, chi-square analysis, $\left.P<0.01, n=627\right)$. 


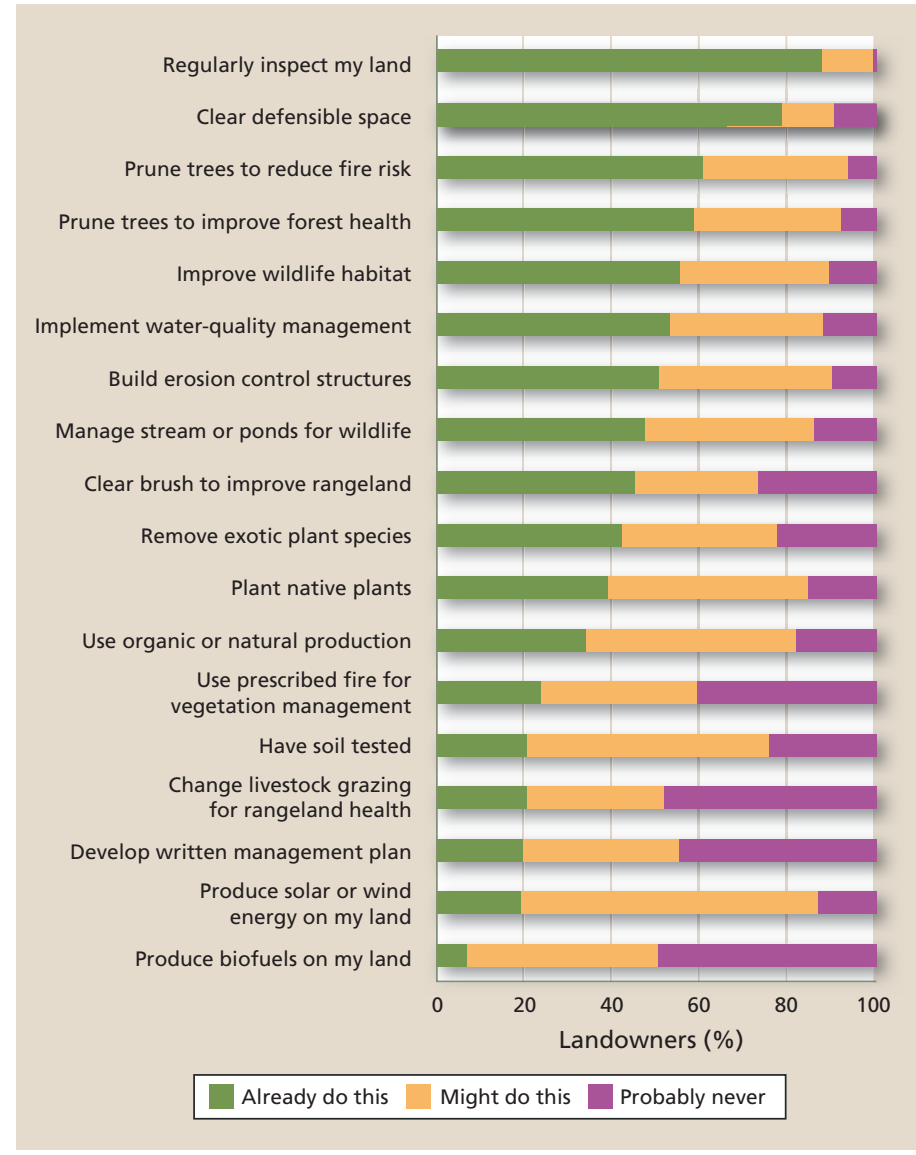

Fig. 5. Management practices used by California forest and rangeland owners $(n=615), 2008$.

improvement (fig. 5). Almost all respondents regularly inspected the condition of their land. Over half (for whom the question was applicable) cleared defensible space to reduce fire risk; pruned or cut trees to reduce fire risk or improve forest health; improved wildlife habitat; implemented water-quality management practices; or built erosion control structures (fig. 5). Of those who did not use these practices, many would consider using them in the future. For all of the management practices surveyed, over half of all respondents either currently implemented or would consider the practice in the future. Some practices, such as generating solar or wind energy, or testing the soil, although not currently implemented by many, were of interest to many landowners and may be areas where outreach could improve implementation.

Overall, owners of large properties were more likely to carry out or be interested in environmental improvements than owners of smaller properties. In particular, as the property size increased, landowners were notably more likely to improve wildlife habitat, remove exotic plants, implement water-quality management prac-

tices, have their soil tested, develop a written management plan, build erosion control structures or manage streams for wildlife (fig. 6). Practices such as clearing defensible space or pruning or cutting down trees to reduce fire risk were as common on small properties as they were on large ones.

\section{Conservation programs}

Only one-third of all respondents had participated in one of the land management or conservation programs identified in our survey (see box, page 189). The Williamson Act (California Land Conservation Act) program had the most participants, followed by the Timberland Production Zone (TPZ) program. These programs provide property tax reductions to eligible participants to encourage agricultural land (Williamson Act) or forest (TPZ) conservation. The Environmental
Quality Incentives Program (EQIP) and the California Forest Improvement Program (CFIP) had the next highest participation (fig. 7).

These programs provide technical and financial assistance to landowners to address natural resource concerns on private land. Less than $5 \%$ of landowners reported that they had a written rangeland water-quality management plan; participated in the Wildlife Habitat Incentives Program (WHIP) under the U.S. Forest Service, which provides technical and financial assistance; had forest certification, a third-party certification of sustainable forest management operations; had a conservation easement limiting development on their property; had organic certification, ensuring that food is grown according to organic standards; or had received a grant from the California State Water Resources Control Board to 


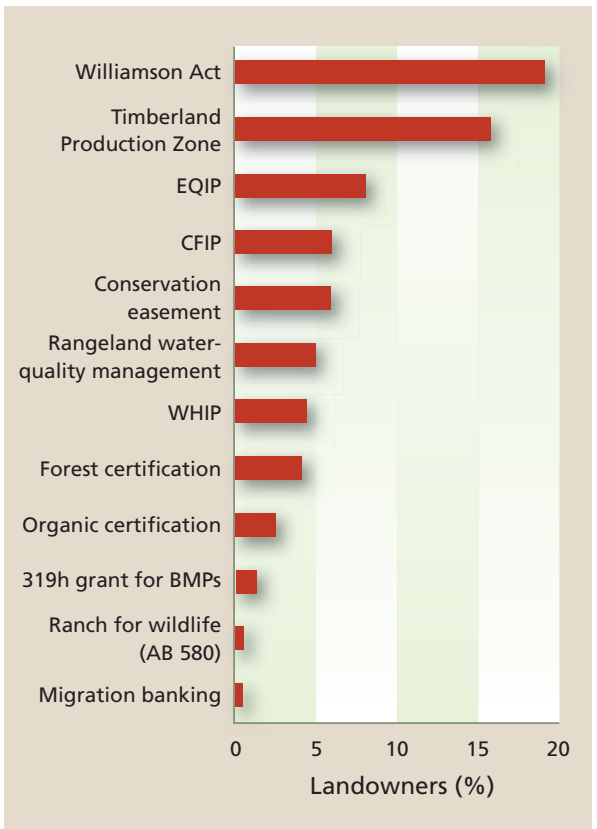

Fig. 7. California forest and rangeland owners participating in land management or conservation programs $(n=624), 2008$.

implement water-quality improvements (319h grant for BMPs). Less than 1\% of landowners reported participating in the Ranch for Wildlife Program (AB 580, now known as the Private Land Management Program of the California Department of Fish and Game), which offers increased fee-hunting opportunities in exchange for habitat improvements on private land; or participated in mitigation banking, a third-party system in which landowners protect or restore wetlands or streams on their property to compensate for impacts to wetlands and streams elsewhere.

Participation varied only slightly based on property size, and in most instances owners of the largest properties (500 or more acres) were no more likely to participate in land management or conservation programs than owners of smaller properties.

\section{Future intentions for land use}

When asked about their long-term plans, almost two-thirds of respondents reported that they planned to pass their land on to children or other family members, while one-sixth planned to sell their land. Few landowners were undecided or had never thought about it. Owners of large properties (500 or more acres) were more likely to plan to pass their land to children and less likely to sell than owners with other property sizes (table 3).

\section{The role of land conservation programs}

T and conservation programs can reward landowners for not fragmenting or developing their land, but only a small percentage of landowners participate in these programs (fig. 7), and most are tailored toward production-oriented ownership. We asked about three land conservation programs in the survey.

Williamson Act (California Land Conservation Act) enrollment. The program with the highest participation (19\%) was the Williamson Act. This program reduces property taxes on agricultural properties through a rolling 10-year contract between landowners and counties, while the state provides funding to compensate counties for all or a part of the property tax losses. The 45-year-old Williamson Act is widely supported by agricultural groups, landowners, county governments and environmentalists as a method to restrict the conversion of farms and ranches to urban uses, but its fate is tenuous due to recent state budget cuts (Sokolow 2010). The program is also not accessible to all landowners. The specifications for enrolling include having a property large enough for commercial use and located within a county-designated "agricultural preserve," as well as other requirements set by each county. To change the land use without penalty, a landowner must stop renewing the contract and wait 9 years while property taxes gradually increase to normal levels. About 15 million acres were enrolled in 2010, with 9 million on "nonprime" sites typical of rangelands.

Timberland Production Zone (TPZ) designation. The TPZ program had the second highest participation (16\%). County governments initially classified lands as TPZs in the 1970s, but landowners can petition to change the county zoning. Lands zoned as TPZs have larger minimum parcel sizes and limitations on residential uses. Similar to the Williamson Act, TPZs have specific acreage and site requirements that vary by county. The landowner receives a lower tax assessment based on timber production rather than development potential. A successful petition for rezoning and a 10-year period of gradually increasing property taxes are needed to remove land from a TPZ without penalties. About 4.3 million of the 5.6 million acres in TPZ designation in 2010 are owned by forestry businesses, and the rest are owned by families.

Conservation easement establishment. Conservation easements, in contrast, can be implemented on any type of landscape with conservation value. A landowner voluntarily gives up the development rights for a property in return for a monetary payment and/or tax reductions (Gustanski and Squires 2000). The development rights are then held by a land trust or agency and recorded in the property title. The easement may also have other provisions such as limitations on particular practices, but these are individually negotiated for each property. Over the last decade, conservation easements have become an increasingly important conservation tool, but like other conservation programs, they are limited by the level of private donations to land trusts and the availability of public funds. Only $6 \%$ of the landowners surveyed had conservation easements on all or part of their property.

Mitigation easements. Mitigation easements are another form of environmentally oriented easement; although they were not asked about in the survey, some respondents may have treated them as conservation easements. Mitigation easements are similar to conservation easements in that they change the property title to restrict certain activities. However, they are funded when a developer has to mitigate, for example, habitat loss for a particular species. The landowner agrees to provide that habitat, and anything that might harm it is permanently restricted from the area.

Limitations of land conservation programs. Limitations in available funding and the high transaction costs per project make these programs inaccessible to the vast majority of landowners (fig. 7). Programs for large properties can preserve the greatest number of acres with the least logistical overhead. Still, with continuing fragmentation in California's forests and rangelands, it will become increasingly important to consider the ecosystem services provided by moderate- to small-sized properties and adopt more comprehensive strategies to preserve these services. 
TABLE 3. California forest and rangeland owners' future intentions for their land $(n=595), 2008^{*}$

\begin{tabular}{|c|c|c|c|c|c|}
\hline Future intentions & $\begin{array}{c}\text { All } \\
\text { landowners }\end{array}$ & 3 to 9 acres & $\begin{array}{l}10 \text { to } 49 \\
\text { acres }\end{array}$ & $\begin{array}{l}50 \text { to } 499 \\
\text { acres }\end{array}$ & $\begin{array}{c}500 \text { or more } \\
\text { acres }\end{array}$ \\
\hline & 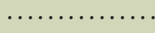 & 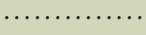 & $\ldots \%$ & ( & .......... \\
\hline $\begin{array}{l}\text { Pass to children or family } \\
\text { member }\end{array}$ & 62 & 48 & 63 & 61 & 79 \\
\hline Sell & 16 & 26 & 13 & 18 & 6 \\
\hline Undecided & 11 & 12 & 14 & 11 & 5 \\
\hline Other & 6 & 7 & 5 & 5 & 9 \\
\hline Never thought about & 3 & 7 & 3 & 2 & 0 \\
\hline Donate & 2 & 1 & 2 & 2 & 1 \\
\hline
\end{tabular}

Landowners were also asked what reasons would influence a hypothetical future decision to sell their land. Almost $20 \%$ reported that none of the reasons applied to them because they would never sell. Of the remaining $80 \%$, just over half chose "it is too much work to maintain," followed by "can't afford to keep it," "property taxes too expensive," "to finance retirement" and "inheritance taxes too expensive" (fig. 8).

Development pressure. A high percentage $(43 \%)$ of landowners reported that they had been previously approached to sell their property for development. As property size increased, landowners were significantly more likely to have been approached $\left(\chi^{2}=86.4, P<0.0005\right)$. Of the owners of large properties (500 or more acres), 73\% had been approached, compared with $49 \%$ for 50 to 499 acres, 32\% for 10 to 49 acres and $21 \%$ for the smallest properties.

Conservation easements. Conservation easements are voluntary contracts between a landowner and land trust or agency that restrict real estate development, certain land-use practices, and other relevant activities on private property in exchange for payment or tax relief for the owner. Of the landowners surveyed, 41 had a conservation easement on their property (unweighted data), or $6 \%$ of all landowners from the weighted sample. Because of this small number, all subsequent statistics on easement holders are unweighted. There were no significant differences in easements based on property size. Together, the 41 easements covered approximately 41,000 acres and represented $3 \%$ of the total acres reported. Of the 41 landowners, 30\% indicated that they sold the easement, $30 \%$ donated the easement, $13 \%$ reported a combination of selling and donating, and 28\% purchased the property with an existing easement.

Easements were sold or donated to more than 23 different land trusts. Pacific Forest Trust, a regional land trust focused on protecting private working forests, held seven easements from our sample. Two-thirds of the easements were obtained since 2000. The most popular reasons for selling or donating the easement were "to conserve the land," "for tax benefit" and "to preserve land for heirs." When asked whether they would sell or donate the easement again, 92\% of landowners said they would.

Although most respondents did not have a conservation easement, there was general interest: $33 \%$ of owners without easements indicated that they would consider selling one in the future, and 9\% would consider donating an easement. Another 34\% indicated that they did not know enough about easements to make a decision.

\section{Ownership trends, fragmentation}

Although a small percentage of the surveyed forest and rangeland owners earned income from their land, the majority earned little to no income; they predominantly benefited from its amenity and investment value. Only landowners with the largest properties ranked ownership objectives such as "family tradition or business" and "income source" as important reasons for owning their land and reported income-generating land uses (figs. 3 and 4A).

These results are consistent with other studies of California landowners. In a study of California oak woodland owners with more than 20 acres, Campos et al. (2009) found that landowners were willing to forgo significantly greater income from using their land equity for alternate investments in order to keep their land and enjoy its amenities. Drawing on the same population of oak woodland owners, Huntsinger et al. (2010) found that while the acreage grazed by livestock has remained relatively consistent since 1992, the number of owners selling livestock declined, reliance on other income sources increased and the number of owners with small parcels increased.

These findings imply an overall shift from production-oriented owners to amenity and investor ownership in California forests and rangelands. The shift is more pronounced among smaller properties. How this shift might influence the ecological integrity of California's forests and

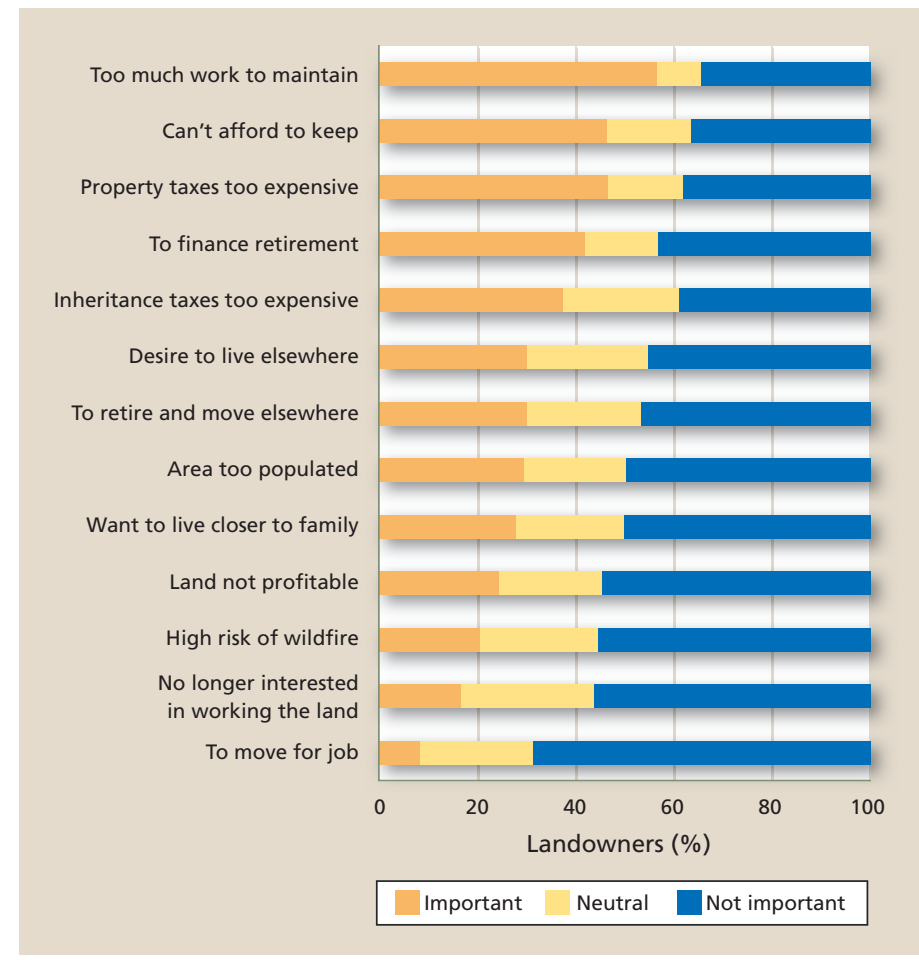

Fig. 8. Reasons California forest and rangeland owners stated they might sell their land someday $(n=552), 2008$. 
rangelands is not clear. Rural landowners clearly value the scenic qualities of their land - the most common reason chosen for owning land was to "live near natural beauty." "Preservation" and "protecting the environment" were also important to a strong majority of landowners of all property sizes (figs. 2 and 3), indicating that many feel a sense of stewardship and want to preserve their land's scenic and environmental qualities. Many of these qualities provide ecosystem services that are shared by society and benefit the public (Huntsinger et al. 2010).

However, owners of large properties, the category with the longest land tenures, were more likely than smaller landowners to implement environmental management or improvement practices (fig. 6). These results raise the question of whether fragmentation may affect environmental health by facilitating an in-migration of landowners less likely to implement environmental practices. Addressing this question will be an important challenge for conservation in California. The fact that landowners from all property sizes expressed widespread interest in implementing environmental management practices in the future gives cause for optimism, and it highlights the importance of outreach and assistance designed to help landowners better manage their properties.

Landowners face land management costs as well as liquidity challenges when

\section{References}

Alig RJ, Plantinga AJ. 2004. Future forestland area: Impacts from population growth and other factors that affect land values. J Forest 102:19-24.

Brown DG, Johnson KM, Loveland TR, Theobald DM

2005. Rural land-use trends in the conterminous United States, 1950-2000. Ecol Appl 15:1851-63.

Butler BJ, Leatherberry EC. 2004. America's family forest owners. J Forest 102:4-9.

Campos P, Oviedo JL, Caparros A, et al. 2009. Contingent valuation of woodland-owner private amenities in Spain, Portugal and California. Rangeland Ecol Manag 62:240-52

[CDFFP] California Department of Forestry and Fire Protection. 2003. The Changing California: Forest and Range 2003 Assessment. Sacramento, CA. http://frap.cdf.ca.gov/ assessment2003.

Clendenning G, Field DR, Jensen D. 2004. A survey of seasonal and permanent landowners in Wisconsin's Northwoods: Following Dillman and then some. Soc Natur Resour 17:431-42.

Dillman DA. 2007. Mail and Internet Surveys: The Tailored Design Method (2nd ed.). New York: Wiley. 464 p.

Gosnell H, Haggerty JH, Travis WR. 2006. Ranchland ownership change in the greater Yellowstone ecosystem 1990-2001: Implications for conservation. Soc Natur Resour 19:743-58. a major portion of their assets is tied up in forest and rangeland. Four of the five most popular reasons why respondents might someday sell their land were related to financial concerns (fig. 8). California has some of the highest land values in the country (Kroll 2009), and landowners can tap into this monetary value only if they choose to sell land or some of the associated development, timber harvesting, mineral or other rights. Since landowners obtain significant amenity benefits from moderate to small properties (Campos et al. 2009), owners of large properties can capture considerable monetary value by selling off parcels, while still maintaining the quality of life they value on their remaining, slightly smaller, property. In fact, this is a tradition among cash-poor livestock producers.

\section{Future of privately owned lands}

What will happen when privately owned forests and rangelands change ownership - either through generational transfer of land or sale - is unknown. Family land transfers across the United States are expected to be substantial in the next 10 to 20 years (Butler and Leatherberry 2004). California forest and rangeland owners are 62 years old on average, with a high proportion retired, and many more nearing retirement. The majority of these landowners, especially owners of large properties, plan to pass ownership on to their children or family

Gustanski JA, Squires RH (eds.). 2000. Protecting the Land: Conservation Easements Past, Present and Future. Washing ton, DC: Island Pr. $566 \mathrm{p}$

Hansen AJ, Knight R, Marzluff JM, et al. 2005. Effects of exurban development on biodiversity: Patterns, mechanisms and research needs. Ecol Appl 15:1893-905.

Hobbs NT, Galvin KA, Stokes CJ, et al. 2008. Fragmentation of rangelands: Implications for humans, animals and landscapes. Global Env Chang 18:776-85.

Huntsinger L, Johnson M, Stafford M, Fried J. 2010. California hardwood rangeland landowners 1985 to 2004: Ecoystem services, production and permanence. Rangeland Ecol Manag 63:325-34.

Jones RE, Fly JM, Talley J, Cordell HK. 2003. Green migration into rural America: The new frontier of environmentalism. Soc Natur Resour 16:221-38.

Kendra A, Hull B. 2005. Motivations and behaviors of new forest owners in Virginia. Forest Sci 51:142-54.

Kroll CA. 2009. California Housing in the Subprime/Credit Crisis - Overview and a Forward Look at Recovery. UC Berkeley Fisher Center for Real Estate and Urban Economics. http://escholarship.org/uc/item/9h1898m1. Maestas JD, Knight RL, Gilgert WC. 2003. Biodiversity across a rural land-use gradient. Conserv Biol 17:1425-34 Maletta H. 2007. Weighting. www.spsstools.net/Tutorials/ WEIGHTING.pdf. members. Without proper estate planning, inheritance taxes and disagreements among heirs could make it difficult for many families to keep their properties. Without technical knowledge on environmental management and improvement practices, it may be difficult to maintain the desired amenities.

New owners, through inheritance or in-migration, may bring a new set of ownership goals and objectives, or the current trend toward valuing amenities more than revenue generation may continue. It will be important to update knowledge of these landowners so that forestry and range professionals can effectively provide advice, assistance and outreach, and encourage protection of the ecosystem services that support quality of life for all Californians.

S. Ferranto is Ph.D. Candidate, Department of Environmental Science, Policy and Management, UC Berkeley; L. Huntsinger is Professor, Department of Environmental Science, Policy and Management, UC Berkeley; C. Getz is Associate Cooperative Extension Specialist, UC Berkeley; G. Nakamura is UC Cooperative Extension (UCCE) Specialist, Shasta County (retired); W. Stewart is Cooperative Extension Specialist, UC Berkeley; S. Drill is Natural Resources Advisor, UCCE LOS Angeles County; Y. Valachovic is Forest Advisor and County Director, UCCE Del Norte County; M. DeLasaux is Natural Resources Advisor, UCCE Plumas-Sierra; and M. Kelly is Cooperative Extension Specialist and Adjunct Professor, Department of Environmental Science, Policy and Management, UC Berkeley.

Moritz MA, Stephens SL. 2008. Fire and sustainability: Considerations for California's altered future climate. Clim Change 87:265-71

Nowak DJ, Walton JT. 2005. Projected urban growth (2000-2050) and its estimated impact on the U.S. forest resource. J Forest 103:383-9.

Parmenter AW, Hansen A, Kennedy RE, et al. 2003. Land use and land cover change in the greater Yellowstone ecosystem: 1975-1995. Ecol Appl 13:687-703.

Sokolow A. 2010. Outlook: Budget cuts threaten the Williamson Act, California's longstanding farmland protection program. Cal Ag 64:118-20.

Theobald DM. 2005. Landscape patterns of exurban growth in the USA from 1980 to 2020. Ecol Soc 10:32. Walker P, Fortmann L. 2003. Whose landscape? A political ecology of the "exurban" Sierra. Cult Geogr 10:469-91. White EM, Morzillo AT, Alig RJ. 2009. Past and projected rural land conversion in the U.S. at state, regional and national levels. Landscape Urban Plan 89:37-48.

Yung L, Belsky JM. 2007. Private property rights and community goods: Negotiating landowner cooperation amid changing ownership on the Rocky Mountain Front. Soc Natur Resour 20:689-703 